\title{
Uptake of zinc by cultured phytoplankters Hymenomonas elongata
}

\author{
M. Gnassia-Barelli, M. Roméo \\ I.N.S.E.R.M. Institut National de la Santé et la Recherche Médicalé, U. 303, BP 3, F-06230 Villefranche-Sur-Mer, France
}

\begin{abstract}
Uptake of zinc by Hymenomonas elongata (Haptophyceae) was studied as a function of concentration in medium (from 25 to $600 \mu \mathrm{gl}^{-1}$ ) and of exposure time. Freundlich adsorption isotherms turned out to be a function of zinc concentration with saturation at values $>150 \mu \mathrm{g} \mathrm{Zn} l^{-1}$. Zinc uptake at $150 \mu \mathrm{g}^{-1}$ as a function of incubation time also followed saturation curves. In the dark, cells contaminated for $24 \mathrm{~h}$ and $48 \mathrm{~h}$ with zinc took up significantly less zinc than those placed in the light. Darkness or treatment of algae with DCMU, a powerful inhibitor of photosynthesis, strongly reduced zinc uptake. Cells killed by glutaraldehyde fixation took up significantly less zinc over $48 \mathrm{~h}$ than living cells. Zinc uptake by $H$. elongata is, thus, a light-dependent process, which seems to be linked to cell metabolism.
\end{abstract}

\section{INTRODUCTION}

If introduced into aquatic ecosystems at high concentrations, zinc can constitute a hazard for living organisms. Large quantities of zinc are released annually into coastal marine waters off densely populated regions (Young et al. 1980). Hence it is important to understand the ways and forms in which this metal is taken up by marine organisms. Toxicity and accumulation of zinc in cultivated phytoplankton species have been studied extensively (Hayward 1969, Davies 1973, Jensen et al. 1974, Braek et al. 1980). Nevertheless, recent work (Bates et al. 1983, 1985) stresses the need for investigating the main physical and biological processes involved in the fixation of zinc by phytoplankton, such as adsorption, transmembrane transport and metabolism.

We have studied zinc uptake by the phytoplankter Hymenomonas elongata at the end of the exponential growth phase. In order to analyse the uptake mechanism, the influence of zinc concentration, incubation time and light were examined.

\section{MATERIALS AND METHODS}

Belonging to the Haptophyceae, Hymenomonas elongata (Droop) Parke \& Green was previously named Cricosphaera elongata. This coastal plankton species has been studied extensively in regard to its cadmium and copper uptake capabilities (Gnassia-Barelli \& Härdstedt-Roméo 1982). In the present study, it was cultured at $18 \pm 1{ }^{\circ} \mathrm{C}$ under a $12 \mathrm{~h}$ light: $12 \mathrm{~h}$ dark regime $\left(E=95 \mathrm{~W} \mathrm{~m}^{-2}\right)$ in bacteria-free conditions. Cells were grown in $f / 2$ medium (Guillard \& Ryther 1962) diluted $50 \times$ with filtered seawater; this allows a high growth rate without introducing metals or chelators at too high a concentration. Thus, the concentrations of EDTA, iron and zinc were $0.2,0.2$ and $0.002 \mu \mathrm{M}$, respectively. EDTA concentration should not influence the amount of free $\mathrm{Zn}$ in the medium in zinc uptake experiments. Concentrations of nitrate and phosphate were $0.88 \mathrm{mM} \mathrm{NaNO}_{3}$ and $36.3 \mu \mathrm{M}$ $\mathrm{NaH}_{2} \mathrm{PO}_{4}$, respectively, in order to avoid nutrient limitation during the experiments. Both nitrate and phosphate concentrations in the culture medium were monitored as growth proceeded, and never turned out to act as limiting factors. Inocula were obtained from an axenic stock culture and placed in $5 \mathrm{l}$ of culture medium.

In this paper, light accumulation refers to a $12 \mathrm{~h}$ light: $12 \mathrm{~h}$ dark photoperiod; dark accumulation, to continuous darkness.

Experiment I examined the influence of zinc concentration on zinc accumulation during a constant incubation time $(48 \mathrm{~h})$. Aliquots of $500 \mathrm{ml}$ of the cultures were collected at the end of the exponential growth phase and exposed to different zinc concentrations $(25,50$, 100,150 and $300 \mu \mathrm{g} \mathrm{l}^{-1}$ ) for $48 \mathrm{~h}$. The end of the exponential phase was determined according to results 
reported by Karez et al. (in press) where zinc uptake (at $150 \mathrm{\mu g}^{-1}$ ) by Hymenomonas elongata was found to vary as a function of the growth phase with a maximum at the end of the exponential phase.

Experiment II investigated zinc uptake (at $150 \mu \mathrm{g}$ $\mathrm{Zn} \mathrm{l}^{-1}$ ) by Hymenomonas elongata as a function of incubation time $(0.5,24,48,72$ and $96 \mathrm{~h})$. It employed several $500 \mathrm{ml}$ aliquots of exponentially growing cells.

Experiment III was designed to determine whether or not the mechanism of zinc uptake was light dependent. Cultures in exponential phase were transferred to a dark room $\left(18^{\circ} \mathrm{C}\right) 48 \mathrm{~h}$ before adding the metal to the culture medium and hence in the absence of photosynthesis. Uptake in the dark $\left(150 \mu \mathrm{g} \mathrm{Zn} \mathrm{I}^{-1}\right)$ was studied as a function of exposure time $(0.5,24$ or $48 \mathrm{~h})$. This process was also studied as a function of the time ( 0 and $12 \mathrm{~h}$ ) during which the cells were kept in the dark before zinc addition.

The effect of the photosynthesis inhibitor 3-(3,4-dichlorophenyl)-1,1-dimethylured (DCMU) on zinc uptake was tested in Experiment IV. DCMU was dissolved in a minimum amount of ethanol. In a previous experiment, ethanol at low concentration was found to have no effect on zinc uptake. Two h after the introduction of zinc $\left(150 \mu \mathrm{g} \mathrm{l}^{-1}\right)$, DCMU was added to cultures which contained exponentially growing cells, resulting in a final concentration of $10^{-5} \mathrm{M}$. The kinetics of zinc uptake were then followed. Finally, cells previously killed by glutaraldehyde $(0.1 \%)$ fixation were treated with $150 \mu \mathrm{g} \mathrm{Zn} \mathrm{l}^{-1}$ for $48 \mathrm{~h}$, and their zinc uptake was measured.

Growth rate of the cultures was recorded by triplicate cell counts using a Lemaur haemacytometer.

At the end of each uptake experiment, zinc-treated or control cultures were filtered through $8.0 \mu \mathrm{m}$ 'Sartorius' membrane filters for metal analyses by flame atomic absorption spectrophotometry as described in Gnassia-Barelli \& Hädstedt-Roméo (1982). Because of the difficulties inherent in measuring cell weights, results were expressed in $\mathrm{ng} \mathrm{Zn}$ per $10^{6}$ cells. Values were corrected for metal retention on blank filters.

\section{RESULTS}

The effect of zinc concentration on zinc uptake by Hymenomonas elongata (Experiment I) is shown in Fig. 1. Significant zinc accumulation was observed in treated cells, compared to controls which contained 65 $\pm 22 \mathrm{ng} \mathrm{Zn} 10^{-6}$ cells ( $\mathrm{n}=13$ )

The relation between particulate zinc associated with the cells and soluble zinc was calculated, giving the power function.

$$
\text { partic. } \mathrm{Zn}\left(\mathrm{ng} 10^{-6} \text { cells }\right)=42 \mathrm{Zn}^{0656}\left(\mathrm{ug} \mathrm{l}^{-1}\right)
$$

The correlation coefficient $r=0.896(n=20)$ was significant at the 0.0001 level. The $\pm 95 \%$ confidence limit of the regression coefficient 0.656 was \pm 0.134 .

Results of zinc accumulation (at $150 \mu \mathrm{g} \mathrm{1}^{-1}$ ) as a function of exposure time (Experiment II) are presented in Fig. 2. Zinc levels increased as a function of exposure time: after 24, 48 and $96 \mathrm{~h}$, Hymenomonas elongata cells had a mean zinc content of 899,1329 and $1521 \mathrm{ng}$ per $10^{6}$ cells, respectively. This is expressed by the equation:

$$
\text { partic. Zn (ng } 10^{-6} \text { cells) }=214 \mathrm{t}^{0.506}(\mathrm{~h})
$$

The correlation coefficient $r=0.983(\mathrm{n}=31)$ was significant at the 0.0001 level. The $\pm 95 \%$ confidence limit of the regression coefficient 0.506 was \pm 0.030 .

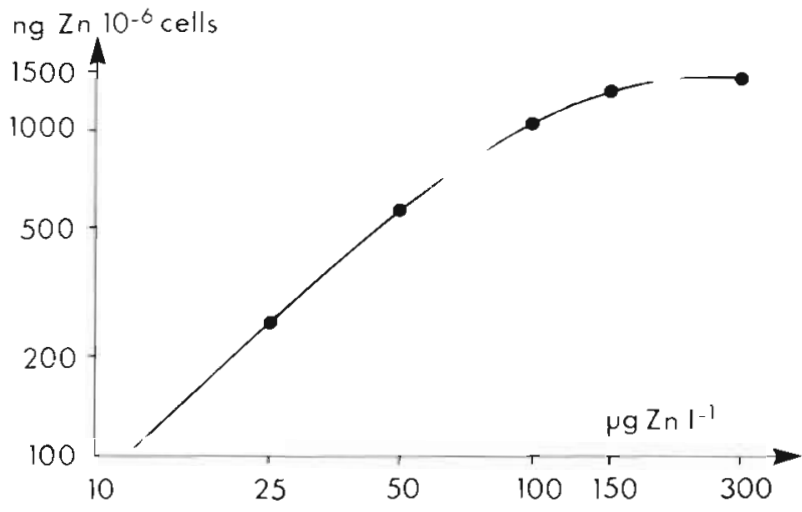

Fig. 1 Hymenomonas elongata. Zinc uptake as a function of zinc concentration in the medium (log-log plot)

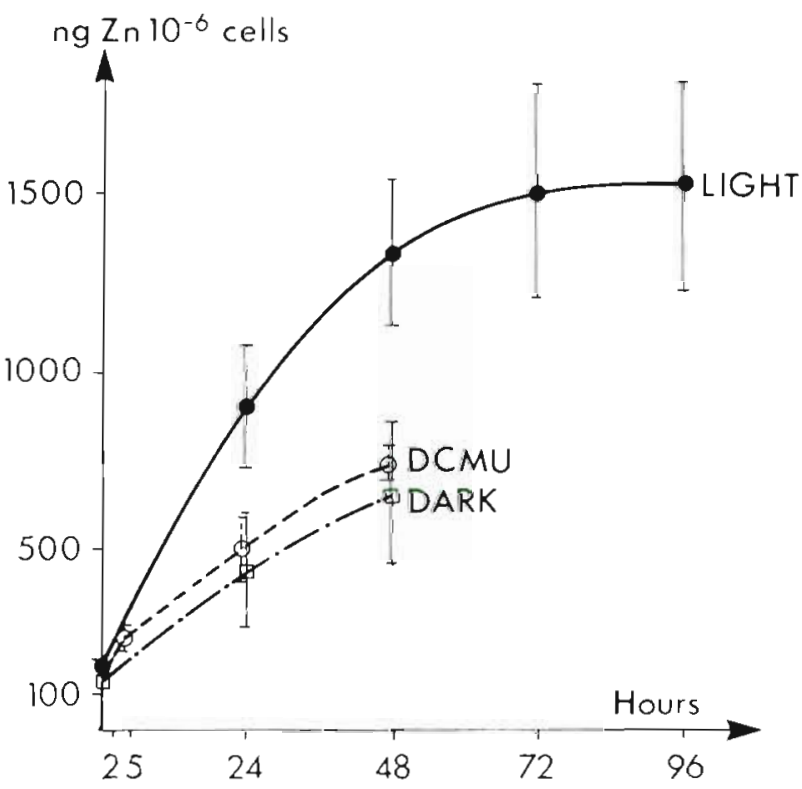

Fig. 2. Hymenomonas elongata. Uptake of zinc at $150 \mathrm{\mu g} \mathrm{l}^{-1}$ as a function of exposure time (b) in the light, in presence of DCMU $10^{-5} \mathrm{M}$ in the light (both after exposure to $12: 12$ photoperiod) and in the dark following dark pretreatment 
Results of Experiment III are also shown in Fig. 2. Within the first $30 \mathrm{~min}$, darkness had no effect on zinc accumulation at $150 \mu \mathrm{g} \mathrm{l^{-1 }}$, compared to the experiments conducted in the light. A significant effect was noted for an exposure time of 24 and $48 \mathrm{~h}$ for cells placed in the dark $48 \mathrm{~h}$ before introducing the metal. Compared to Experiment II, accumulation over $48 \mathrm{~h}$ in the dark was reduced to ca $50 \%$ of the corresponding light values

The equation found for the uptake in the dark as a function of time is:

$$
\text { partic. Zn }\left(\mathrm{ng} 10^{-6} \text { cells }\right)=169 \mathrm{t}^{0.310}(\mathrm{~h})
$$

where $r=0.745(n=11)$, significant at the 0.01 level. This result is significantly different from that obtained in the light since the $\pm 95 \%$ confidence limit of the regression coefficient 0.310 is \pm 0.016 .

Uptake of zinc by Hymenomonas elongata in the dark was strongly influenced by the period of time the cells were kept in the dark before adding the metal. When the dark incubation period was shortened (12 h) or omitted, uptake over $48 \mathrm{~h}$ was similar to that in the light.

The results of Experiment IV are also shown in Fig. 2. After a $3 \mathrm{~h}$ treatment with DCMU, zinc uptake by cells contaminated with $150 \mu \mathrm{g} \mathrm{Znl^{-1 }}$ for $5 \mathrm{~h}$ seemed unchanged; following longer treatment (22 or $46 \mathrm{~h}$ ) with DCMU, uptake was reduced to $44 \%$ of the light values in both cases

Cells killed by glutaraldehyde fixation took up significantly less zinc for $48 \mathrm{~h}\left(162 \pm 52 \mathrm{ng} \mathrm{Zn} 10^{-6}\right.$ cells, $\mathrm{n}=3)$ than living cells $\left(1329 \pm 215 \mathrm{ng} \mathrm{Zn} 10^{-6}\right.$ cells, $n=5)$.

During experiments carried out at zinc concentrations ranging from 25 to $300 \mu \mathrm{g} \mathrm{l^{-1 }}$, no apparent toxic effect was observed, whereas duplicate uptake experi- ments conducted under the same conditions, but with $600 \mu \mathrm{g} \mathrm{Zn} \mathrm{I}^{-1}$ for $48 \mathrm{~h}$, revealed a toxic effect. At the end of the experiments, treated cells were aggregated, a small percentage had broken up, and some were larger than the control cells or those incubated in 25 to $300 \mu \mathrm{g} \mathrm{l}^{-1}$. Fig. 3 shows contaminated cells $1600 \mu \mathrm{g}$ $\mathrm{Zn} \mathrm{l}^{-1}$ ) compared to a control cell. The zinc content of the cells contaminated with $600 \mu \mathrm{g} \mathrm{Zn} 1^{-1}$ was respectively 142 and $151 \mathrm{ng}$ per $10^{6}$ cells; this level is significantly lower than that found in cells incubated at concentrations $\leqslant 300 \mu \mathrm{gl}^{-1}$ (Fig. 1). This suggests a probably important zinc loss by damaged cells.

\section{DISCUSSION}

Over the concentration range 25 to $300 \mu \mathrm{g} \mathrm{Zn} \mathrm{l}^{-1}$, zinc uptake as a function of zinc concentration added to the culture medium followed a power function and can be described by a Freundlich adsorption isotherm, $y=$ $\mathrm{aC}^{\mathrm{b}}$, where $\mathrm{y}=$ amount of zinc adsorbed by the cells; $\mathrm{C}=$ concentration of zinc in solution; $\mathrm{a}$ and $\mathrm{b}=$ constants. This function gives a straight line in a log-log plot. Where the slope of the isotherm differs from 1 , uptake depends on the concentration of the sorbable ion in the medium. In the case of zinc uptake by Hymenomonas elongata as a function of zinc concentration in the medium, the slope was 0.656 . For concentrations $>150 \mu \mathrm{g} \mathrm{Zn} \mathrm{l^{-1 }}$, deviation from linear relationship was observed (Fig. 1); this suggests saturation of binding sites.

Consequently, the concentration of $150 \mu \mathrm{g} \mathrm{Zn} \mathrm{l}{ }^{-1}$ was chosen for the following uptake experiments carried out as a function of time in light and dark.

The zinc concentration chosen was very high compared to that in the open sea $\left(<200 \mathrm{ng} \mathrm{l}^{-1}\right)$, reported for
Fig. 3. Hymenomonas elongata. (a) Normal cell $(\times 1600)$; (b) contaminated cells after treatment

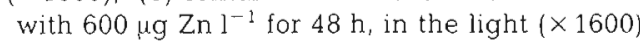

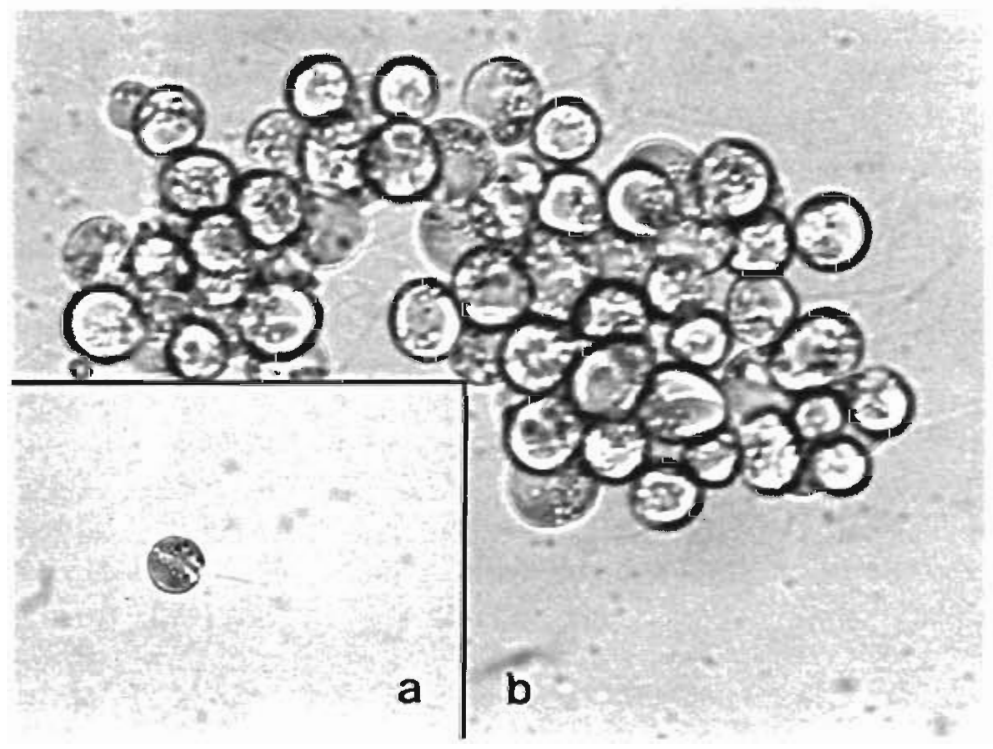


the Western North Atlantic by Bruland \& Franks (1983), but it may be found in polluted estuarine and coastal waters (Bryan 1984).

Zinc uptake by Hymenomonas elongata cells as a function of time follows a saturation process. Saturation is reached after $72 \mathrm{~h}$. The same time exponent as that calculated for zinc accumulation by $H$. elongata (0.5) was found for zinc taken up by Phaeodactylum tricornutum (Davies 1973), and also reported for other metals: mercury accumulated by Isochrysis galbana (Davies 1974) and by Dunaliella tertiolecta (Davies 1976), and cadmium taken up by Prasinocladus marinus (Roméo \& Gnassia-Barelli 1985).

Our experiments in the dark or in the presence of DCMU (which inhibits photosynthesis) clearly show that zinc uptake by Hymenomonas elongata is light dependent.

Findenegg et al. (1971), investigating light dependence of the uptake of ${ }^{65} \mathrm{Zn}$ by Chlorella fusca, concluded that it occurs both by rapid ion-exchange at the cell wall and by a slower metabolic-dependent process.

Gutknecht $(1961,1963)$ showed that ${ }^{65} \mathrm{Zn}$ uptake by the algae Ulva lactuca and Porphyra umbilicalis was stimulated by illumination and temperature increase. Increase in $\mathrm{pH}$ of the surrounding medium increased ${ }^{65} \mathrm{Zn}$ uptake and thus, ${ }^{65} \mathrm{Zn}$ uptake was considered a passive process, affected indirectly by metabolism.

Our results show that zinc uptake may be related to the metabolism of Hymenomonas elongata since dark incubation reduced uptake. When the dark incubation period was shortened or omitted, the cells had not yet used up their energetic reserves and were still able to take up zinc even in the dark. Moreover, cells previously killed by glutaraldehyde did not accumulate zinc from the solution. Parry \& Hayward (1973) reported that dead Dunaliella tertiolecta took up ${ }^{55} \mathrm{Zn}$ but that this uptake ceased after $1 \mathrm{~h}$. The accumulation, which was also temperature and $\mathrm{pH}$ dependent, appeared to be indirectly linked to metabolism. On the other hand, as shown in our previous paper (Karez et al. in press), zinc uptake by $H$. elongata revealed a maximum at the end of the exponential phase which corresponded to the maximum level of cellular proteins.

From the present experiments, it cannot be concluded that zinc penetrates the cells of Hymenomonas elongata. Nevertheless, the time exponent 0.5 found for zinc uptake at $150 \mu \mathrm{g} \mathrm{l}^{-1}$ as a function of time is according to Crank (1970), characteristic of a diffusion-controlled process. Rapid adsorption may occur on the extracellular binding sites of $H$. elongata, followed by a slower diffusion of zinc inwards into the cytoplasm, related to metabolic rate. Moreover, Karez et al. (in press) reported that only $40 \%$ of the accumulated zinc at $150 \mu \mathrm{g} \mathrm{l}^{-1}$ was removed by EDTA from cells of $H$. elongata previously exposed for at least
$24 \mathrm{~h}$. Zinc is therefore strongly linked to $\mathrm{H}$. elongata cells, either to the surface or the cytoplasm. On the other hand, the deleterious effect observed at $600 \mu \mathrm{g}$ $\mathrm{Zn} \mathrm{I}^{-1}$ may imply zinc penetration causing toxicity inside the cell. Bates et al. (1985) distinguished between zinc adsorbed by Chlamydomonas variabilis and zinc transported into the cytoplasm; the latter increases with dissolved zinc (until a toxic level is reached) and with the culture age.

In conclusion, zinc uptake by Hymenomonas elongata depends on the metal concentration added to the medium and on incubation time. It is a light-dependent process which might be linked to metabolic rate. Experiments with ${ }^{65} \mathrm{Zn}$ would allow more insight into the metabolic pathways.

\section{LITERATURE CITED}

Bates, S. S., Létourneau, M., Tessier, A., Campbell, P. G. C. (1983). Variation in zinc adsorption and transport during growth of Chlamydomonas variabilis (Chlorophyceae) in batch culture with daily addition of zinc. Can. J. Fish. Aquat. Sci. 40: 895-904

Bates, S. S., Tessier, A., Campbell, P. G. C., Létourneau, M. (1985). Zinc-phosphorus interactions and variation in zinc accumulation during growth of Chlamydomonas variabilis (Chlorophyceae) in batch culture. Can. J. Fish. Aquat. Sci. 42: $86-94$

Braek, G. S., Malnes, D., Jensen, A. (1980). Heavy metal tolerance of marine phytoplankton. IV. Combined effects of zinc and cadmium on growth and uptake in some marine diatoms. J. exp. mar. Biol. Ecol 42: 39-54

Bruland, K. W. Franks, R. P. (1983). Mn, Ni, Cu, $\mathrm{Zn}$ and $\mathrm{Cd}$ in the Western North Atlantic. In: Wong C. S., Boyle, E., Bruland, K. W., Burton, J. D., Goldberg, E. D. (ed.) Trace metals in sea water. Plenum Press, New York, p. 415-426

Bryan, G. W. (1984). Pollution due to heavy metals and their compounds. In: Kinne, O. (ed.) Marine ecology, Vol. 5, Ocean management, Part. 3. John Wiley \& Sons, Chichester, p. 1289-1431

Crank, J. (1970). The mathematics of diffusion. University Press, Oxford

Davies, A. G. (1973). The kinetics of and a preliminary model for the uptake of radio-zinc by Phaeodactylum tricornutum in culture. In: Proceedings of a Symposium. Seattle, 1972, Radioactive Contamination of the Marine Environment. International Atomic Energy Agency, Vienna, p. 403-420

Davies, A. G. (1974). The growth kinetics of Isochrysis galbana in cultures containing sublethal concentrations of mercuric chloride. J. mar biol. Ass. U. K. 54. 157-169

Davies, A. G. (1976). An assessment of the basis of mercury tolerance in Dunaliella tertiolecta. J. mar. biol. Ass. U. K. 56: 39-57

Findenegg, G. R., Paschinger, H., Broda, E. (1971). Untersuchung der Lichtabhängigkeit der Aufnahme von Rubidium, Zink, Kobalt, Blei und Cer durch Chlorella nach einer Flußmethode. Planta (Berl.) 99: 163-173

Gnassia-Barelli, M. Härdstedt-Roméo, M. (1982). Short-term time series study of copper and cadmium uptake by Cricosphaera elongata (Droop) Braarud. J. exp. mar. Biol. Ecol. $61 \quad 287-298$ 
Guillard, R. R. L., Ryther, J. H. (1962). Studies of marine planktonic diatoms. I. Cyclotella nana Hustedt and Detonula confervacea (Cleve) Gran. Can. J. Microbiol. 8: 229-239

Gutknecht, J. (1961). Mechanisms of radioactive zinc uptake by Ulva lactuca. Limnol. Oceanogr. 6: 426-431

Gutknecht, J. (1963). ${ }^{65} \mathrm{Zn}$ uptake by benthic marine algae. Limnol. Oceanogr 8: $31-38$

Hayward, J. (1969). Studies on the growth of Phaeodactylum tricornutum. $V$ The relationship to iron, manganese and zinc. J. mar. biol. Ass. U. K. 49:439-446

Jensen, A., Rystad, B., Melsom, S. (1974). Heavy metal tolerance of marine phytoplankton. I. The tolerance of three algal species to zinc in coastal sea water. J. exp. mar. Biol. Ecol. 15: 145-157
Karez, C. S., Roméo, M., Gnassia-Barelli, M. (in press). Uptake of $\mathrm{Zn}$ and $\mathrm{Cd}$ by a coastal phytoplankton species in culture. In: Lacerda, L. D., Seeliger, U. (ed.) Metals in coastal environments of Latin America. Springer-Verlag, Berlin

Parry, G. D. R., Hayward, J. (1973). The uptake of ${ }^{65} \mathrm{Zn}$ by Dunaliella tertiolecta Butcher. J. mar. biol. Ass. U. K. 53 915-922

Roméo, M., Gnassia-Barelli, M. (1985). Metal uptake by different species of phytoplankton in culture. Hydrobiologia 123: 205-209

Young, D. R., Jan, T K., Hershelman, G. P. (1980). Cycling of zinc in the nearshore marine environment. In: Nriagu, J. O. (ed.) Zinc in the environment, Part. I. Ecological cycling John Wiley \& Sons, New York, p. 297-337

Responsible Subject Editor. Professor S. Bonotto; accepted for printing on July 2, 1987 